\title{
Castration Anxiety and the Mirror Stage: A Psychoanalytic Reading of Shakespeare's Othello
}

\author{
Shadi S. Neimneh ${ }^{1, *} \&$ Nisreen M. Sawwa ${ }^{1}$ \\ ${ }^{1}$ English Department, Hashemite University, Jordan \\ *Correspondence: English Department, Hashemite University, Zarqa 13115, Jordan. Tel: 962-779-148-865. E-mail: \\ shadin@hu.edu.jo
}

Received: June 3, 2015

Accepted: June 6, 2015 Online Published: June 17, 2015

doi:10.5430/wjel.v5n2p25

URL: http://dx.doi.org/10.5430/wjel.v5n2p25

\begin{abstract}
This article mainly applies two psychoanalytic notions to Shakespeare's tragedy Othello (1622), namely castration anxiety and the mirror stage. It argues that Othello is strengthened by Desdemona and his high military rank as the general of the Venetian army. Against common postcolonial readings of the play, we argue that Othello experiences castration anxiety metaphorically, i.e. he gets anxious about losing such things that make him strong in Venice. In addition, Othello goes through the mirror stage metaphorically as well. He makes the assumptions that he is backed up by his military rank and his wife, that Iago is honest with him, and that the absence of the handkerchief-which signifies loyalty to him-indicates that his wife is unfaithful to him. After he believes Iago's lie that his wife has an affair with Cassio, Othello gets so anxious that he kills his wife, and after realizing that his assumptions have been all false and that he is castrated and no longer attached to his wife and his post, he self-destructively commits suicide. Othello's anxiety about losing his authority and his shattered self-image as a betrayed husband are ultimately intertwined. Hence, this article offers fresh insights into Shakespearean plays by reading one representative piece, Othello, against some trends in literary theory not known during Shakespeare's times but universal in their application to literary texts.
\end{abstract}

Keywords: William Shakespeare; Othello, the Moor of Venice; psychoanalysis; castration anxiety; the mirror stage

\section{Introduction}

William Shakespeare's Othello, the Moor of Venice (written between 1601and 1604 and published in 1622) is a tragedy that has often been discussed and analyzed from a postcolonial perspective because the fact that Othello is a black makes him discriminated against by the whites in Venice. However, it can be argued that Othello is partially discriminated against because he is appointed as the general of the Venetian army and Desdemona, a white woman, is married to him. This article does not apply postcolonial theory to the play. It is not our goal to reiterate Othello's exotic traits or outsider racial status in Venice, as one would do in a typical postcolonial reading of the play. The "otherness" Othello embodies as a non-white North-African Moor or as a marginalized figure seeking acceptance by a foreign Venetian culture and experiencing identity issues has been discussed by critics like Sandeep Dubey (2015) and Alina Popa (2013). Rather, this article mainly applies two psychoanalytic concepts to offer fresh insights into a well-known Shakespearean drama: castration anxiety and the mirror stage. In the Comprehensive Dictionary of Psychoanalysis (2009), the term psychoanalysis is defined as "a procedure for the investigation of mental processes which are almost inaccessible in any other way (p. 229). This article aims to analyze the character and the mentality of Othello, showing how he figuratively undergoes castration anxiety and the mirror stage before he gets dominated by a self-destructive drive that leads him to his own death, what we can label as the Freudian "Thanatos."

In fact, this article is an attempt at character analysis from a psychological level. Our goal is analyzing Othello's personality in terms of development and hidden motivation. This character is an anxious figure in a psychoanalytic sense. Both Lacan and Freud saw fear of castration as "an integral part of our psychosexual development" (Felluga, 2011, "Castration Complex"). Social laws and prohibitions thwart a child's primitive desires like incest and murder. Lacan developed this castration anxiety as the "Law of the Father," which means restrictions and laws controlling our desires and actions. For Lacan, this acts in a similar way to the super-ego. On the other hand, Lacan's mirror 
stage is tantamount to the narcissitic formation of "Ideal-I" or "ideal ego" before the entry into the symbolic realm of language (Felluga, 2011, "Mirror Stage"). The mirror stage is part of the imaginary order for Lacan. It is that idealistic image of self we want to emulate or have. As Lois Tyson (2006) argues, the mirror stage is the realm of satisfactory images and perception of self as whole or complete in a relation of interdependence with the mother and control over the environment (p. 27). Othello is anxious about losing his authority and his intact image in the Venetian society, i.e. his ideal "I".

The literal meaning of castration anxiety is given by Thurschwell (2000) who has stated that in the Freudian theory, the castration complex or castration anxiety is the fear of the loss of the penis for boys and the recognition of the loss of the penis for girls. In addition, the boy fears that the girl used to have a penis but it has been removed. The present article is not concerned with this literal meaning of castration anxiety. It rather employs this notion in its symbolic sense. The article argues that Othello's high military rank as well as Desdemona's love for him are symbols of power like the phallus for men. Othello is a good soldier and an efficient leader for the Venetian government. In a sense, he is the adequate, whole man for the state. As a result, Othello is anxious about losing these two things that strengthen him. After Othello loses his confidence in Desdemona, he turns into a criminal killing her, and after losing his job, he kills himself. So, he figures out that his life is meaningless and that he is castrated without these two things that give him power. In this figurative sense, castration means loss of power, authority, and influence. Othello has been exercising this castrating power over others like Iago by passing him over for the position of a lieutenant. He then strips Cassio of this position and wounds Iago after he discovers the latter's treachery. However, he is made to experience both castration anxiety and the shattering of his ego-ideal.

The article also employs the Lacanian notion "the mirror stage", which is Jacques Lacan's psychoanalytic notion of the formation of the ego. Lacan (2006) stresses the importance of the mirror stage, in that it is helpful in understanding the construction and recognition of the self or the $I$. The mirror stage takes place when children between the ages of six and eighteen months, who cannot walk at this age and who are supported by another person or a device while walking, see how they look in the mirror and then assume or form illusory images of themselves. Lacan argues that when children see the images of their bodies in the mirror, they form ideal images of themselves that are imaginary "the Ideal-I". Lacan also emphasizes the illusion or mirage in the mirror stage, arguing that the images formed in this stage are fantasies; he says: "The jubilant assumption [assomption] of his specular image by the kind of being - still trapped in his motor impotence and nursling dependence - the little man is at the infans stage thus seems to me to manifest in an exemplary situation the symbolic matrix in which the $I$ is precipitated in a primordial form, prior to being objectified in the dialectic of identification with the other, and before language restores to it, in the universal, its function as subject" (p.76).

Lacan also states that when children see the total form of the body, they assume the maturation of their power or mastery. This article employs the mirror stage symbolically, arguing that Othello assumes that Desdemona and his military rank strengthen him and give him an ideal self-image of being in control of his environment, so he gets anxious about losing them or being separated from them. Othello also assumes that he is strong because of his adventures and his post as the general of the Venetian army, things that make him accepted by others including Desdemona. In addition, he assumes that Iago is a man of honesty, and this explains why he believes every word uttered by Iago.

Lacan also refers to Oedipus Complex that touches on the social norm, "the incest taboo". People should abide by this norm and other social norms. Othello assumes that the handkerchief signifies faithfulness to the partner, which is a norm women should conform to, so the absence of the handkerchief means that his wife is unfaithful to him. For Othello, unfaithfulness to the partner is prohibited and not tolerated, just like incest in Sophocles' Oedipus the King. Oedipal anxiety is unconscious, but it gets manifested in certain actions that reveal the repression of sexual desire and fear from the patriarchal authority of the father figure. The Comprehensive Dictionary of Psychoanalysis (2009) states that according to Lacan, "'alienation' is the inevitable consequence of the subject's identification with its specular image during the "mirror stage" (p. 11). At the end of the play, Othello realizes that the images he has projected on others and his own assumptions are false, for his strength and his post have not saved him from being tried for killing Desdemona, and he has been blinded to the truth and lied to by Iago, so he commits suicide. He alienates himself because he has realized that he is separated from his post and his wife, without which he is castrated, i.e. lacking as a man and socially inadequate.

\section{Castration Anxiety}

Taylor (2000) has provided a number of definitions for the word "castration." One of these definitions is that 
castration "posits that all human children believe that females are males who have had their genitalia completely cut off as a punishment for their perverse desires" (p. iii). Freud stresses that boys fear to be castrated by their fathers as a punishment for having incestuous desires for their mothers. The fact that the girls envy the boys for having the penis and the fact that the boys fear that they may lose the penis - or the phallus as a supreme signifier of desire-indicate that the penis symbolizes precious power. Being a Moor in a racist white society makes Othello discriminated against by some of the characters in the play who call him "the Moor" or other racist terms. Bartels (1997) refers to how Othello is named by Roderigo and Iago as "the thick-lips", "an old black ram", "the devil", "a Barbary horse", etc (p. 45). Desdemona's father also discriminates against Othello; he gets angry with his daughter when he learns that she has married Othello, and he tells the Duke that his daughter has been stolen from him by charms and spells. However, Othello believes that his high military rank - as a phallic symbol — will save him before the Duke, saying to Iago: "My parts, my title and my perfect soul/ Shall manifest me rightly. Is it they?" (Shakespeare, 2005, 1. 2. 31-32).

Othello believes that he has been loved by Desdemona because of his strength. When Desdemona's father accuses Othello of being a thief stealing Desdemona and forcing her to marry him, Othello says: "She loved me for the dangers I had pass'd,/ And I loved her that she did pity them." (1.3. 167-168). Othello believes that the stories about his adventures and the battles he has participated in appeal to Desdemona because they show that he is strong. So, Othello's strength signifies power since he has been assigned as the general of the army because of his strength. In addition, the fact that Desdemona confirms what Othello has said to the Duke and the fact that she expresses her love for Othello before her father must strengthen Othello. As a general of the army, Othello cares about his decisions and his reputation. For example, one of the final decisions he has taken is when he has dismissed Cassio from his job because Cassio has stabbed Montano; Othello tells Cassio: "... Cassio, I love thee/ But never more be officer of mine (2. 3. 248-249) and says to Montano: "...for your hurts, myself will be your surgeon" (2. 3. 254). Officers in the army do care about their reputation. Cassio, for example, says after he is dismissed from his job:

Reputation, reputation, reputation! O, I

have lost my reputation! I have lost the immortal

part of myself, and what remains is bestial. (2. 3. 262-264).

It can be argued that Othello has dismissed Cassio from his post, though he loves him, and that he has attempted to soothe Montano because as a general of an army, Othello has to be firm with others; otherwise, he may lose his job. Having this high military rank makes Othello anxious about losing it, so he does his best to keep his job and his reputation as a decisive leader. This may explain why Othello does not forgive Cassio though Desdemona has asked him to forgive Cassio and reappoint him as a lieutenant many times.

Othello does not fear to be castrated by the father for having incestuous desires for the mother as boys do; he rather fears that Desdemona's love may be taken away from him by the white man Cassio. In other words, Othello's love for a white woman makes him anxious about losing this love object, believing that he does not have the qualities the white men have, so his love, as a black man, for a white woman might be considered as prohibited incest. Othello says:

To pray at fortune. Haply, for I am black

And have not those soft parts of conversation

That chamberers have, or for I am declined

Into the vale of years, - yet that's not much-(3.3.263-266)

Othello claims that Desdemona has loved him because of his adventures and strength, so if he had not told Desdemona appealing stories about himself, she would have probably loved a white man. So, Othello believes that he is not worth loving as the white men are, which makes him fear to be castrated by a white man who may win Desdemona's heart.

Iago takes advantage of the fact that Othello is anxious about losing the things that make him more powerful, so he decides to make Othello lose the two things that strengthen him, i.e. his military rank and the trust in his wife. Iago attempts and manages to make Othello lose his trust in his wife, Desdemona. Iago once sees Cassio holding Desdemona's hand while talking to her, so he decides to convince Othello that his wife cheats on him. Iago's wife, Emilia, is Desdemona's attendant, which makes Iago make use of this as well. Iago tells Othello that he has heard Cassio call out Desdemona's name in his sleep, and he suspects Desdemona and Cassio to be in love. This makes Othello get anxious about losing his wife's love for him; he says: "She's gone. I am abused; and my relief/ Must be to 
loathe her. O curse of marriage," (3. 3. 267-268). Othello gets so anxious about losing his wife that he does not search for a piece of evidence himself, but rather he asks Iago to prove to him that his wife has a love affair with Cassio, which indicates his fear and anxiety as a man who might lose his love object and his contingent masculinity to another man.

Iago also makes use of the fact that Othello is a simple person who believes every lie Iago tells. Othello has described Iago once saying that "This fellow's of exceeding honesty, /And knows all qualities, with a learned spirit," (3. 3. 258-259). Iago convinces Cassio to talk to Desdemona and ask her to convince Othello to forgive him and reappoint him as a lieutenant. Everything goes according to Iago's plans. Othello becomes doubtful about his wife's faithfulness to him after she keeps asking him to forgive Cassio. Moreover, since Iago's wife is Desdemona's attendant, Iago asks her to bring him the handkerchief that Othello has given to Desdemona as a gift. The handkerchief is so important for Othello; it is symbolic of masculine vigor. Othello tells Desdemona that his mother has used it to keep his father faithful to her. The handkerchief means a lot to Othello, and he regards it as a sign of fidelity for him. Emilia gives the handkerchief to her husband who convinces Othello that Desdemona has given the handkerchief to Cassio, which angers Othello because the loss of the handkerchief means that Desdemona is cheating on him. This makes Othello get mad, and he once strikes her before Lodovico. Then Othello decides to kill both Cassio and his wife after he thinks he is sure that his wife has an affair with Cassio. Iago talks to Cassio about Cassio's mistress, Bianca, making Othello, who hides nearby, think that they are talking about Desdemona. What makes him more certain is Bianca holding the handkerchief which Cassio has found in his room and has given to Bianca, and accusing Cassio to be in love with another woman. This makes Othello's blood boil and turns him into another person.

Othello becomes ready to commit a crime because after losing his trust in Desdemona, he feels that he has lost his power and everything. He tragically smothers her, not trying to believe her though she insists on defending herself to the end. In a sense, he castrates himself and becomes less strong since his wife is one of the sources of his strength. When he is told by Emilia that Desdemona is faithful to him and that she has been asked by Iago to steal the handkerchief, he finds out that he has been mistaken, and he regrets killing his wife and castrating himself in his new incomplete state.

After he has lost Desdemona, Othello is left with one thing that strengthens him, i.e. his military rank. However, he has been deprived of his power, dismissed from his job, and asked to be put on trial since he has killed his wife. Since Othello has lost the two things that give him power, he tragically kills himself like Oedipus of Sophocles's famous play who figuratively castrates himself by putting out his eyes after he discovers that he has been sleeping with his mother and that he killed his father. Othello has been castrated, in the symbolic sense of castration as death or loss of power. He kills himself because he has nothing to lose. The two important things that make him powerful in this society have come to an end, so he kills himself because without these two things, he is castrated and his life is meaningless. Othello says before he stabs himself:

I have done the state some service, and they know't.

No more of that. I pray you, in your letters,

When you shall these unlucky deeds relate,

Speak of me as I am; nothing extenuate,

Nor set down aught in malice: then must you speak

Of one that loved not wisely but too well;

Of one not easily jealous, but being wrought. (5.2. 338-344)

The last words Othello says before committing suicide indicate that he cares about his reputation and job that used to make him strong. He laments the loss of his wife and his job, without which he is castrated, fearing to acquire a bad reputation after he dies; and thus he begs others to speak objectively of him and reminding others of his achievements and the services he has done for Venice.

\section{The Mirror Stage}

According to Lacan (2006), children between the ages of six and eighteen months look in the mirror and form illusory images of themselves. Children at this age depend on others; for example, they cannot stand to see themselves in the mirror if not helped by others or walkers. When Iago tells Othello that Desdemona's father will 
divorce him and Desdemona, Othello says: "My services which I have done the signiory/ Shall out-tongue his complaints. 'Tis yet to know,--" (1.2. 18-19) and "My parts, my title and my perfect soul/ Shall manifest me rightly. Is it they?" (1.2. 31-32). Othello forms an illusory image when he jubilantly assumes that his strength, which is part of him, makes him accepted in Venice since his strength has helped him marry Desdemona and get assigned as the general of the Venetian army. He believes that his strength and the services he has done for the Venetian government will save him and help him to defend himself before the Duke and Desdemona's father. In addition, Othello says that he has won Desdemona's heart with the help of the stories he has told her about his adventures. Being a black man in a society that discriminates against people of color makes Othello in need of something to lean on. In other words, Othello makes use of his strength and his adventures to be strong in Venice, where he is discriminated against. Moreover, for the Duke and Desdemona's father to believe him, he asks them to verify whether Desdemona loves him or not by asking her, saying: "Here comes the lady; let her witness it" (1.3.170); Othello needs Desdemona to confirm what he has said. So, he feels that he cannot stand alone, and thus he needs to be supported by his wife, his military rank and his achievements, all things that make him an ideal man and husband.

It has been aforementioned that Othello assumes that Iago is honest with him, so Iago, who detests Othello, takes advantage of this and tries to convince Othello that Desdemona has an affair with Cassio. Othello has said: "She's gone. I am abused; and my relief/ Must be to loathe her. O curse of marriage," (3.3. 267-268). One of the conventional social norms women must abide by is being faithful to their husbands and attached to them. The image Othello used to have of Desdemona is an ideal image of a typical wife conforming to moral standards. Therefore, he gets anxious when told by Iago that his wife cheats on him, feeling offended and deceived as a man. So, Othello asks Iago to provide him with a piece of evidence, saying to him: "Villain, be sure thou prove my love a whore,/ Be sure of it; give me the ocular proof:" (3.3. 359-360). Iago uses the handkerchief that Othello has given to Desdemona as a piece of evidence. The handkerchief is very important to Othello. It signifies marital fidelity for him, and he assumes that the absence or loss of the handkerchief means that his wife is not faithful to him. Othello tells Desdemona that the handkerchief has been given to his mother by an Egyptian woman who has told her that the handkerchief will make Othello's father loyal to her, provided she keeps it.

To carry out his schemes, Iago starts to arouse Othello's suspicions. For example, he says to Othello:

In sleep I heard him say "Sweet Desdemona,

Let us be wary, let us hide our loves;"

And then, sir, would he gripe and wring my hand,

Cry "O sweet creature!" and then kiss me hard. (3. 3. 419-422)

Iago tells a lie that Cassio professes his love for Desdemona in his sleep. He also plays with words to make Othello jealous by telling the lie that Cassio, in his sleep as well, kisses Iago, imagining that Desdemona is sleeping beside him. To reach his goals, Iago also has Cassio asking Desdemona to convince Othello to reappoint him as a lieutenant. Moreover, Iago has asked his wife to steal the handkerchief and after he has gotten it, he has left it in Cassio's house. When Iago lies to Othello, telling him that Cassio has said that he has lain "With her, on her; what you will." (4.1.34), Othello goes so mad that he goes into a trance since he feels that the ideal image he has projected of his wife is threatened with falsehood and that he may be separated from Desdemona who, like any other woman, must be attached and faithful to her husband. When Othello regains consciousness, Iago asks him to hide nearby and listen to his conversation with Cassio, and as it has been mentioned previously, Othello who has been standing out of earshot has mistakenly believed that Cassio has been talking about his affair with Desdemona though he has been talking about his relationship with Bianca. In addition, when Bianca has entered holding Desdemona's handkerchief and accusing Cassio of being in a relationship with another woman, Othello explodes with rage and says: "I will chop her into messes: cuckold me!" (4.1. 202). After that, he decides to kill Desdemona since she has betrayed him, as he believes. In addition, he strikes Desdemona before Lodovico, and at home he accuses her of being a whore. Then he decides to separate her from him and construct his own self apart from her. As a result, he smothers her, and though she has tried to convince him that she is innocent, he has not believed what she has said because he no longer regards her as inseparable from him. However, when he is told by Emilia that Desdemona has been loyal to him and she herself has given Iago the handkerchief, he regrets and realizes that the image he has had of Iago as an honest person is false and imaginary.

Another imaginary thing he has supposed is the fact that his strength makes him accepted and strong in the society. However, he realizes that he has been mistaken when he is told that he is dismissed from his job and he will be brought to trial, so he has not benefited from his strength as he used to. When Lodovico asks "Where is this rash and 
most unfortunate man?" (5.2. 281), Othello says "That's he that was Othello: here I am" (5.2. 282). As a result, he alienates himself from society and murders himself. He has always thought that his strength, his job, and Desdemona are inseparable from him and will always back him up, but he has found out that this has been just an assumption. He has ultimately seen his real image, the image of a man separated from his wife and his job that make him powerful. This is known as the "recognition of the self," so Othello has recognized himself and his real image at the end and has not accepted to be separated from the things that make him strong. As a result, he alienates himself by committing suicide.

\section{Conclusion}

In conclusion, this article has applied two psychoanalytic theories to Shakespeare's tragic play: castration anxiety and the mirror stage. It has employed the Freudian theory "castration anxiety" and the Lacanian notion "the mirror stage" in their symbolic sense. The article has argued that Othello's high military rank and Desdemona are symbols of power, which makes Othello anxious about losing them. Othello believes that he is backed up and saved by his high military rank and his achievements, so when Desdemona's father accuses him of having stolen Desdemona by charms, he says that the stories he used to tell to Desdemona about his adventures and strength have made Desdemona accept to marry him. Therefore, his strength and high military rank signify power, and so does his marriage to Desdemona who has confirmed what he has said and who has expressed her love for him before the Duke and her father. Othello experiences castration anxiety metaphorically, i.e. he is anxious about losing what strengthens him, and Iago makes use of Othello's anxiety. The first thing Iago manages to do is making Othello dismiss Cassio from his service as a lieutenant. Othello does so because he is serious about the decisions he makes and he does care about his job and reputation.

Another thing Iago makes Othello lose is his trust in his wife Desdemona and his trust in Cassio; Iago convinces Othello that his wife cheats on him by getting Cassio to ask Desdemona to convince Othello to reappoint him as a lieutenant, by getting his wife to steal the handkerchief, which signifies fidelity for Othello, and by leaving the handkerchief in Cassio's room. Therefore, Othello becomes too anxious after the loss of the handkerchief, so he strikes Desdemona before Lodovico not caring about his reputation and he ultimately smothers her in bed. He gets "castrated" after killing her, dismissed from his job and asked to be on trial for murdering his wife, so he commits suicide.

The article has also employed the mirror stage, which is Lacan's notion of the formation of the ego, showing how Othello goes through this stage metaphorically as well. As it has been argued, Othello is strengthened by his wife and his post, so being accepted by his wife because of the stories he has told her and having a high military rank make Othello assume that he has mastery or complete power. He has formed illusory images; for example, he has assumed that Iago is honest with him, and he has assumed that the loss of the handkerchief, that is a signifier of his wife's loyalty to him, means that his wife cheats on him and does not conform to the social norm: faithfulness and attachment to the marriage partner. When Othello starts to believe that his wife is disloyal to him by listening to and believing Iago's words, he gets so anxious that he kills her. Thus, he realizes that the assumption that his wife is inseparable from him is false. In addition, when he is dismissed from his job for killing his wife, he realizes that he is separated from his strength which has been part of him and which has been the thing that makes him accepted and respected in this society. As a result, he chooses to alienate himself after realizing that his assumptions have been false. He does not tolerate the idea that his real self is separable from or whole without Desdemona and his post, and since he is weak without these two things, he stabs himself to death.

\section{References}

Akhtar, S. (2009). Comprehensive dictionary of psychoanalysis. Retrieved April, 16, 2015 from EBSCOhost database.

Bartels, E. (1997). Othello and Africa: Postcolonialism reconsidered. The William and Mary Quarterly, 54(1), 45-64. http://dx.doi.org/10.2307/2953312

Berry, E. (1990). Othello's alienation. Studies in English Literature (Rice), 30(2), 315-333. http://dx.doi.org/10.2307/450520

Dubey, S. (2015). 'Identity' and 'Culture' as postcolonial issues in Shakespeare's Othello. Ars Artium: An International Peer-Reviewed-cum-Refereed Research Journal of Humanities and Social Sciences, 3, 92-98. 
Felluga, D. (2011). Terms used by psychoanalysis. Introductory Guide to Critical Theory. Retrieved Jan. 31. Purdue U. 18/5/2015 from http:/www.purdue.edu/guidetotheory/psychoanalysis/psychterms.html

Gallop, J. (1982/1983). Lacan's "mirror stage": Where to begin. SubStance, 11/12(37-38), 118-128.

Johnson, F. (1975). Psychological alienation, isolation, and self-estrangement. Psychoanalytic Review, 62(3), $369-405$.

Kurzweil, E. (1981). Jacques Lacan: French Freud. Theory and Society, 10(3), $419-438$. http://dx.doi.org/10.1007/BF00179273

Lacan, J. (2006). Ecrits. (B. Fink, Trans.). Retrieved from http://users.clas.ufl.edu/burt/Lacan.pdf

Popa, A. (2013). Post-colonialism in Shakespearean work. Annals of the "Constantin Brancusi" University of Targu Jiu, Letter and Social Sciences Series, Issue 4.

Shakespeare, W. (2005). Othello, the Moor of Venice. St. Paul, Minnesota: EMC/ Paradigm Publishing.

Taylor, G. (2000). Castration: An abbreviated history of Western manhood. Retrieved May 2, 2015 from EBSCOhost database.

Thurschwell, P. (2000). Sexuality. In Sigmund Freud (chap. 3, pp. 43-60). Retrieved from Literary Reference Center database.

Tyson, L. (2006). Critical theory today: A user friendly guide. (2 ${ }^{\text {nd }}$ ed.). New York: Routledge. 